\title{
DREAM AND REALITY IN THE POETRY OF DAVID GASCOIGNE (LINGUISTIC ANALYSIS OF THE POEM AND THE SEVENTH DREAM IS THE DREAM OF ISIS)
}

\author{
Liudmyla Pradivlianna ${ }^{1}$
}

\begin{abstract}
Surrealism, the XX century literature and art movement, inspired an impressive number of scientific research regarding different aspects of the phenomenon. This paper studies surrealism as a type of artistic thinking which raised the role of the unconscious in poetry. It focuses on the core of surrealist aesthetics - an automatic image, which allowed the poets to study human irrational states, such as dreams. Focusing on the themes of dreams and dream-like narrations, surrealists created poetry which was formed by specific images. An automatic image coming directly from one's unconscious mind was expected to reveal new knowledge about the world and people. But as the poet 'functions' only as a conductor of the unconscious images, it is the reader who has to create meanings in this kind of poetry. The paper regards surrealism in terms of a lingvo-poetic experiment and analyzes the linguistic characteristics of the automatic texts in the early poetic collection of David Gascoyne (1916-2001). It outlines the peculiarities of the British poet's techniques which are built upon French surrealist concepts and theories and examines phonetic, semantic and syntactic aspects of his poetry. David Gascoyne's lyrics demonstrates the poet's commitment to the French version of surrealism, his interest in the unconscious and dream-like narration. The streams of arbitrary visual images, deep emotionality, the artistic use of the word, semantic increments of meaning make Gascoigne's texts open to interpretation. And though the poet actually prefers visual effects (we rather see dreams), specific dream-like patterns are created not only by lexical, but also by phonetic repetitions, via intonation in which lexemes acquire a new semantic load.
\end{abstract}

Keywords

Surrealism, André Breton, automatic writing, dream-like narration, David Gascoyne, surrealist image.

1. Introduction. Surrealist poetry has always been quite difficult to read. Today, however, the difficulties which one experiences when dealing with the phenomenon of surrealism as a whole, in our opinion, are the result of the overuse of the term surrealism and its derivatives surrealist, surreality, which are widely exploited to denote everything unusual and not explicable. That's the price surrealism pays for "its pop-cultural popularity"2.

People at large associate surreality with the bizarre and the hallucinatory. In 2016, the word surreal was announced Merriam-Webster's Word of the Year and defined as "marked by the intense irrational reality of a dream" and synonymic to unbelievable and fantastic. Over years since Andre Breton and his group launched the new movement in 1924, discoveries and techniques of surrealist poets and artists began to be used toward the commercial ends leaving behind much of surrealism's initial rebellion against rationalism/logic and its focus on releasing the creative potential of a liberated mind. The gap between the original surrealism and its modern perception continues to grow.

1 Assistant Prof., L. Pradivlianna, Cand. of Philol. Sc., National Pedagogical Dragomanov University; vul. Turgenivs'ka, 8/14, Kyiv, Ukraine; E-mail: lyu2005pra@gmail.com ORCID ID: 0000-0003-1752-8613

${ }^{2}$ Jałocha 2016, 75

${ }^{3}$ Drout 2008, 6

${ }^{4}$ Quinn 1985, 6

${ }^{5}$ Ster'jopulu 2008, 30
In our research, we offer to return to surrealism as an avant-garde, primarily poetic school. As Professor Michael D.C. Drout ${ }^{3}$ once said, "poetry is the supreme linguistic achievement of the human species", it gives insight into spiritual development of the human race. The study of surrealism as a lingvo-poetic experiment will contribute to better understanding of the poetry that seeks access to the unconscious. Thus, the object of our work is the surrealist methods of automatic writing and dream-like poetry and the subject - their linguistic characteristics. The purpose of this paper is to outline the peculiarities of surrealist techniques in the early poetry of David Gascoyne (British poet) and to identify and analyze linguistic features of his texts, namely phonetic, semantic and syntactic aspects, which are built upon French surrealist concepts and theories.

Background and motivation. Analysis of scientific literature on surrealism reveals an impressive number of theoretical studies conducted on various aspects of surrealist activities (political, artistic, poetic, etc). Shortage of direct textual research of the poetry though is usually justified by its complexity which seldom makes surrealist poems "the objects of fond perusals"4.

Despite quite fair remarks of those researchers who refuse to study surrealism outside France and Andre Breton's group so as not to "expand the boundaries of surrealism as an organized movement" , and also point to significant differences in the perception of innovative ideas by different national schools (e.g. "In England, the political aspect of surrealism $<\ldots>$ never had the power or attraction that it enjoyed 
in France" and " $<\ldots$.. $>$ was restricted in practice almost exclusively of the visual and literary arts") ${ }^{6}$, we rather agree with the researchers who, like Shelley Quinn, say: "The comparison of images from 'surreal' writers from different countries further facilitates the identification of surreal elements in imagery, and help to isolate these from other modernist characteristics"

David Gascoigne's early work may serve as a worthy example of surrealist writing. Unfortunately, the poet is not well-known in Ukraine. In our research we refer to British sources (Peter Stockwell, R. L. Scott, J.H. Matthews and others $)^{8}$.

There is no reason not to trust Gascoyne as a surrealist poet: at the age of 17 he became the member of Breton group, lived in Paris for a long time, translated into English P. Eluard, B. Pere, A. Breton's theoretical articles. He is the author of the First English Manifesto of Surrealism and Short Survey of Surrealism. His poem And the Seventh Dream is the Dream of Isis, written when the author was just seventeen, represents, according to Michel Remy, "the first surrealist work written in English", and is "Gascoyne's first attempt at 'a purely automatic' surrealist poem" 10 .

It's worth reminding that at the beginning of the group's activities, surrealism and automatism were practically synonymous terms. A. Breton, in his First Manifesto, defined the new movement as "psychic automatism in its pure state" and tried to give it a philosophical justification as an expression of "the actual functioning of thought" which "tends to ruin once and for all all other psychic mechanisms and to substitute itself for them in solving all the principal problems of life" "11. The automatic writing, in its turn, was defined as "a monologue spoken as rapidly as possible without any intervention on the part of the critical faculties, a monologue consequently unencumbered by the slightest inhibition"12. Based on Sigmund Freud's ideas of the dreams and the unconscious and believing that "the depths of our mind contain within it strange forces capable of augmenting those on the surface, or of waging a victorious battle against them"13, the surrealists began working on new ideas connected mainly with the poetic understanding of dreams and their scientific interpretation.

\footnotetext{
${ }^{6}$ Jackaman 1975, 72

${ }^{7}$ Quinn 1985, 11

${ }^{8}$ Stockwell 2017, Scott 2002, Matthews 1964

${ }^{9}$ Remy1999, 32

${ }^{10}$ Scott 2002, 45

${ }^{11}$ Breton 1969, 26

${ }^{12}$ Ibid., 23

${ }^{13}$ Ibid., 10

${ }^{14}$ Lotman 1992, 221-222

${ }^{15}$ Ibid., 224-225

${ }^{16}$ Breton 1969, 151

${ }^{17}$ Ster'jopulu 2008, 48
}

\section{Methodology.}

2.1. The material of the research. In our study we regard the surrealists' works as a manifestation of a certain type of 'surrealist' thinking which got reflected in the language (in case of poetry) and in specific imagery (in the works of visual arts) and examine poetic language as a semiotic system (following the ideas of Yu. Lotman, Yu. Stepanov, R. Barthes). We are especially interested in the works written by the poets who adjoined to the movement from other countries and wrote in different languages (Ukrainian, Russian, English). This, in the long run, might give an insight into how different languages reflect the idea of subconscious so dear to the surrealists. As the material for this article we use the poetic texts the British author David Gascoyne (1916-2001) from the collection Man's Life is This Meat.

2.2. Methods. Our research methods are determined by the specifics of the language material, the subject and the purpose of the study: descriptive method is used to present the main ideas and information about the movement; the methods of linguistic analysis - to examine phonetic and lexical features of the poetic texts. We use the immanent approach to the study of surrealist text which supposes deep analysis of the inner structure of poetry, study of its formal characteristics before making any conclusions regarding its connections with the extra-linguistic phenomena (in our case - the unconscious). Specifics of the surrealist poetry and, especially, the new role of a reader, calls for the use of elements of phenomenology and interpretative semantics in the research.

\section{Results and Discussion.}

3.1. Dream as a topic for philosophic and artistic discussion. Dream had been an artistic motive for centuries long before surrealism, which excited and captivated both poets (W. Shakespeare, S. Coleridge, W. Blake, S. Baudelaire), and artists (series of paintings by F. Goya). Yu.M. Lotman explains that the properties of sleep as a "pure sign", or as a sign in "a pure form" allow it to be "space ready to be filled": "sleep is a semiotic mirror, and everyone sees in it a reflection of their language"14. Obviously, it was this idea of "hidden in the mysterious depths, but potent power that controls a person", and the belief in the "mysterious meaning of dreams"15 that directed the surrealist search towards "the problem of human expression in all its forms"16.

It is on the verge of sleep and reality that surreal, Breton so much relies on, is born. Poets turn to automatic writing and flow of free associations to "extract" true images from the unconscious. Therefore, one of the characteristic features of the surrealist text is "the fusion of the fantastic and the real in the dream-like unity of the world"17. The poet in this world serves as a conductor to the unconscious by constantly honing in on its voice. In his resulting poem he does not explain anything, does not impose meanings, does not encode anything for the reader to, 
as tradition demands, unravel and interpret. "A reader becomes the author" "18. The writer is as objective as possible, he only renders an associative flow of words to the paper. Which is in complete agreement with what psychoanalysts think: "Dreams, witticisms $<\ldots>$ are organized by language. Man is not a talking creature, but a spoken one"19. And Louis Aragon adds: "Meaning is formed outside of us." Hence the increased significance of a WORD.

Many researchers dwell on the role of a word in the surrealist text. L. Andreev: " $<\ldots>$ words are freed from thought; words live their own lives $<$.. $>$ Words are ahead of thought, words formulate thought" 20 . A.Je. Ster'jopulu: "automatic writing $<\ldots>$ is a return to the origins of the language, to its primal matter, to its raw form, $\langle\ldots>$ where the signifier is born and it's not yet permanently connected to its signified, and where words live their own lives" 21 . Andre Breton himself, in his usual metaphorical manner, wrote: "we say "word-play" when it is our surest raison d'être that is at stake. Besides, words have stopped playing. Words are making love"22.

It should be noted that the idea of overcoming the "undividedly terrorist nature of language" (R. Barthes $)^{23}$ - the language as a code, as an established sign system - was dear to other avant-garde poets of the early twentieth century. Suffice to recall V. Khlebnikov and his: "A word controls the brain, the brain hands, the hands - kingdoms" (Khlebnikov) or linguistic experiments of other Russian zaum-poets. In classical poetry a word serves to express a thought, in avant-garde "there are transformations of language at all levels of semiosis. A word as such becomes a self-sufficient unity worthy of itself'24.

The role of surrealism and the revolution it initiated, modern scholars see in the destruction of the old bonds between a word and a thought. "The new system of linguistic relations, built on the basis of the spirit, enabled these poets to create a universe of beauty, the existence of which nobody had previously suspected"25. Andre Breton and his followers, delving into the study of dreams and undermining "the old mental processes through the destruction of logic", found "a whole

\footnotetext{
${ }^{18}$ Stepanov 2006, 38

${ }^{19}$ Mazin 2004, p. 29

${ }^{20}$ Andreev 2004, 101

${ }^{21}$ Ster'jopulu 2008, 60

${ }^{22}$ Aspley 2010, 20

${ }^{23}$ Barthes 1989, 296

${ }^{24}$ Stepanov 2006, 87

${ }^{25}$ Ibid., 726

${ }^{26}$ Ibid.

${ }^{27}$ Cabañas 1997, 47

${ }^{28}$ Scott 2002, 67

${ }^{29}$ Shvec 2008, 60-68

${ }^{30}$ Gascoyne 2019
}

magical world"26. The perception of time, space, causal connections, as they appear in dreams, was transferred to artistic practice through automatic writing. But these were not just "dreams translated into language or literature" but "language clothed as dreams"

3.2. Analysis of David Gascoyne's poetry: phonetic features. The poem And the Seventh Dream is the Dream of Isis was written by David Gascoigne in 1933 and it was his first attempt at automatic writing in the spirit of French surrealism. The poet himself described this period of his life: "I tried to make my mind a blank and wrote down whatever came into my head. It's like a session of psychoanalysis $<\ldots>$ people have clusters of images in their minds and they come out this way $<\ldots>$ a unique combination of new words and images. Surrealist writing is the cultivation of spontaneity"28.

The poem And the Seventh Dream... really produces an impression of being spontaneous. We offer our observations over this work and its language with the idea in mind that the author of surrealist poetry is the reader her/himself, and therefore its readings or perceptions might be different.

So, the title refers to the mythology and to one of the most beloved goddesses of Ancient Egypt Isis, whose husband Osiris was killed and his body dismembered by his brother Set. Grieving Isis gathered the remains of her husband scattered around the world, restored breath and life to his body and miraculously conceived their son. Thereafter she has been revered as the mother of all Egyptian pharaohs ${ }^{29}$.

The seventh dream, however, refers to the Christian prayer of grieving Virgin Mary, who had a prophetic dream of the crucifixion and death of her son.

Neither Christianity nor the Egyptian gods are depicted in the poem. It seems that surreal spontaneity starts right from the title. Yet the mythical and Christian echoes, just like the general tonality of the poem, can 'bind' together what at first glance seems to be an incoherent flow of absurd images:

white curtains of infinite fatigue

dominating the starborn heritage of the colonies of St Francis

white curtains of tortured destinies inheriting the calamities of the plagues of the desert encourage the waistlines of women to expand and the eyes of men to enlarge like pocket-cameras teach children to sin at the age of five to cut out the eyes of their sisters with nail-scissors to run into the streets and offer themselves to unfrocked priests teach insects to invade the deathbeds of rich spinsters and to engrave the foreheads of their footmen with purple signs

for the year is open the year is complete the year is full of unforeseen happenings and the time of earthquakes is at hand $\mathrm{d}^{30}$

(We preserve the original punctuation $-L P$ ) 
This is the first stanza of a rather long free-verse poem. In its form it is somewhat arbitrarily divided into stanzas of different lengths -14 and 9 of not rhyming lines in the first part, 2, 9 and 4 lines in the second, and 46 full lines in the third.

In the above-given passage and further in the poem, all words are written with a small letter (depriving some geographic names like - yorkshire, spain of their "geographical" status), with the exception of St Francis, which, however, is too common a name for cities and Catholic saints to signify anything and therefore it acquirs the characteristics of 'pure sign'.

From the point of view of the syllabo-tonic system, the poem cannot be called metric, and the number of feet in almost every line is different with a tendency to longer lines (5-7 feet) in the middle and shorter (4 feet) at the beginning and end of the stanza. Thus, a certain 'rhythmic pattern' is created which will be repeated in the second stanza of the first part. The number of feet in the entire poem varies from 3 to 7 , while the number of unstressed syllables between the stressed ones is not regulated.

These issues acquire greater significance if we look at them from the point of sound-sense connection, for it's obvious that frequent spondees (two or three stressed syllables in a row) 'cut into' and break a rather tragic-sounding melody of very long lines and thus draw special attention to the stressed lexemes: starborn heritage (reading with the stress on the first syllable only will make it sound like a homonymous stubborn), nail-scissors, deathbeds, rich spinsters, unfrocked priests, and likewise further in the poem - bloodred lilies, white birds fly, ill-fame. The accentuated via the intonation lexemes (contextually used mostly with negative connotations) acquire an additional semantic load, a symbolic character (in this case, perhaps, they speak of the senseless cruelty of the world), becoming a kind of 'signaling' points of the dream-like narrative.

The same phenomenon of 'singling out' phonetically or via intonation of specific concepts which acquire additional semantic features can be observed in another poem - Purified Disgust. The first stanza reads:

An impure sky

A heartless and impure breathing

The fevered breath of logic

And a great bird broke loose

Flapping into the silence with strident cries

A great bird with cruel claws ${ }^{31}$

The sound 'fabric' of the stanza is additionally enhanced due to the peculiar intonation pattern. The only line in which the meter can be identified is the third: The fevered breath of logic, written in an iambic tetrameter, which is quite traditional for the English

\footnotetext{
${ }^{31}$ Gascoyne 1965, 8

${ }^{32}$ Jakobson 1975, 222
}

language, becomes the background against which the spondees stand out clearly: two stressed feet in a row - impure sky, impure breathing, and even four a great bird broke loose, as well as a clear division by caesura of the last line into two parts with two spondees in each - A great bird // with cruel claws.

Lexical and phonetic repetitions attract particular attention: impure sky - impure breathing, and then kind of a phonetic enjambment of impure breathing (long [i:] in breathing) into the next line fevered breath (long [i:] in fevered and short [e] in breath).

Similar 'phonetic enjambment' of consonant sounds [br] in the word breath into similar sounding lexemes in the next line: And a great bird broke loose: [grt], [bd], [brk] and then of [ls] loose into the line Flapping into the silence with strident cries: [fl], [sls], [str], [krz]. The last line sounds like the final chord: A great bird with cruel claws, combining all the repetitions [grt], [bd] - [krl], [klz]. Similar-sounding words do not only create a melody of a verse. According to R. Jacobson, such words acquire paronomastic characteristics and are perceived as one organic whole ${ }^{32}$

Another 'signaling' technique is felt in Gascoyne's dealing with vowel sounds. Most vowels - are the front-row sounds [i:], [e], [ei] (breathing, fevered, breath, great, bird). Now it's quite stunning how on their background 'play' two 'dark' words with the stress on the low back-row vowels heartless ['ha:tlos] and claws [klo:z]. They stand out and complement the image of a bird soaring against the background of an alarmingly impure sky with additional connotative characteristics.

But it's not only with the help of phonetic means that Gascoyne creates his dream-like narratives.

3.2. Analysis of David Gascoyne's poetry: lexical and semantic peculiarities. Examining the poet's word stock in The Seventh Dream ... let's note first the abundance of words of concrete meanings. They can be divided into several semantic fields: civilization (curtains, colonies, pocket-cameras, nail-scissors, streets, deathbed), nature (desert, star, insects, earthquake), person (waistlines of women, the eyes of men, children, the eyes of their sisters the eyes of their sisters, priests, spinsters, foreheads, footmen). Such a great number of concrete images create the impression of layering of the material as in the picture.

Abstract images are also presented through the real, objective ones: white curtains of endless fatigue ... white curtains of tortured destinies. This exceptionally suggestive image is created by the collision of incomparable concepts - of concrete semantics white curtains, which twice describe abstract but understandable to all people images of endless fatigue and tortured destinies. The lexeme white loses its color semantics and brings forth a long associative line - pure, untainted, innocent, and, possibly, meaningless. 
On the background of this all-consuming objectivity, the last three 'abstract' lines of the stanza read in a certain discord:

for the year is open the year is complete

the year is full of unforeseen happenings

and the time of earthquakes is at hand

However, the first line of the next stanza brings us back to the material, visible world:

today is the day when the streets are full of hearses $<\ldots>$

And although in this poem the number of syntactically conflicting images, combinations of semantically incompatible lexemes and metaphors are not significant, yet the real, objective world transforms into illogical dreams and hallucinations, in the sense that ordinary objects and people fall into strange and unusual situations, the poet's fantasy forces them to do things that are contrary to common sense (for example, to cut out the eyes of their sisters with nail-scissors). Images of physical pain and destruction, as well as an almost apocalyptic image and the time of earthquakes is at hand, on the one hand, 'synchronize' with the title of the poem and our knowledge of Virgin Mary and Goddess Isis. On the other hand, there is also a surrealistic denial of all traditional values (Breton: "every means must be worth trying, in order to lay waste to the ideas of family, country, religion (italics - A. Breton)" ${ }^{\prime 33}$ and S. Freud's observation that the most common emotion in a dream is that of anxiety: “... a dream depicts discontent more often than satisfaction" ${ }^{34}$. Dreams, according to Freud, are signals of our desires, often disguised in opposite emotions. So, according to Gascoyne, what do we want to see or not to see behind the white curtains?

Unfortunately, for the limited article-space we cannot make a detailed analysis of this quite long poem but would like to note some important poetic techniques which are used throughout the entire text. First, traditionally surrealistic illogical comparisons which combine the lexemes of different semantics: the hearts of troubadours unfold like soaked mattresses, the arms are like pieces of sandpaper, the gums of queens like glass marbles, etc.

Secondly, frequent use of repetitions, especially commonly met in anaphoric parallel structures. Thus, for example, the second stanza ends with a quatrain: she was standing at the window clothed only in a ribbon

she was burning the eyes of snails in a candle she was eating the excrement of dogs and horses she was writing a letter to the president of franc Repetition she was connects together unrelated segments of the text, forcing the reader to develop parallels between descriptions that have nothing in common. On the other hand, such repetitions create a certain rhythmic pattern and also enhance the visual effect of layering the images on top of each other.

In the poem there are also many simple, scattered all over the text repetitions - the queen, shoeleather, white, a connective word when, resembling a dreamlike obsession, a constant return to certain realities. An interesting repetition of words in the last two lines: and the drums of the hospitals were broken like glass and glass were the faces in the last looking-glass.

If we assume that the three times repeated word glass can acquire a symbolic meaning, then, perhaps, one can discern a desire to look into the unconscious and in its state of being broken like glass again catch the echoes of the myth about Osiris, and in the "glassy" faces in the last looking-glass - predictions about the end of things.

4. Conclusions. Such are, in general, the peculiarities of Gascoyne's surrealist text. It certainly requires constant attention from the reader, who "may obtain pleasure, or displeasure, not from the story itself and what it tells, but by the manner in which it is told" ${ }^{35}$. We would like to agree with the researchers who note the rejection of melody in a surrealist verse because of the frequent use of voiceless consonants and short vowel sounds. Poets actually prefer to focus on the visual effect (we rather see dreams) which is created with the use of special vocabulary. Specific dream-like patterns are created not only by lexical, but also by phonetic repetitions, via intonation in which lexemes acquire a special semantic load and 'signal' additional meanings.

David Gascoyne's lyrics demonstrates British poet's commitment to the French version of surrealism, his interest in the unconscious and dreamlike narration. The streams of arbitrary visual images, deep emotionality, the artistic use of the word, semantic increments of meaning make Gascoigne's texts open to interpretation. Deepening into the philosophy and technique of surrealistic verse is undoubtedly an interesting aspect for further linguistic research.

\footnotetext{
${ }^{33}$ Breton 1969,128

${ }^{34}$ Freud 2010, 132

${ }^{35}$ Cabañas 1997, 206
} 


\section{BIBLIOGRAPHY}

Андреев Л. Г. Сюрреализм = Surrealisme : История. Теория. Практика / Л. Г. Андреев. - Москва : Geleos, 2004. - 350 с. Барт Р. Семиотика. Поэтика (Избранные работы) / Р. Барт. - Москва, Прогресс, 1989. - 616 с. Лотман Ю. М. Культура и взрыв. Семиотика / Ю.М. Лотман - Москва : Прогресс Гнозис, 1992. - 270 с. Мазин В. А. Введение в Лакана / В.А. Мазин. - Москва : Прагматика культуры, 2004. - 196 с. Степанов Ю. С. Семиотика и авангард: антология / Ю. С. Степанов. - Москва : Культура Акад. Проект, 2006. - 1166 с. Стерьёпулу Ап. Элени. Введение в сюрреализм. Пер. Л. Акопяна / Элени Ап. Стерьёпулу. - Львов : БаК, 2008. - 144 с. Фрейд 3. Толкование сновидений [перевод с немецкого] / Зигмунд Фрейд. - Санкт-Петербург : Азбука-классика, 2010. -507 с.

Швец Н. Н. Словарь Египетской Мифологии. Загадки Древнего Египта / Н. Н. Швец. - Москва : Центрполиграф, 2008. - 249 c.

Якобсон Р. Лингвистика и поэтика. Структурализм: «за» и «против» / Р. Якобсон. - Москва, Прогресс, 1975. - С. $193-230$. Aspley K. Historical Dictionary of Surrealism / K. Aspley. - Lanham Md. : Scarecrow Press, 2010. - 545 p.

Breton Andre. Manifestoes of Surrealism / Andre Breton. Translated by Richard Seaver and Helen R. Lane. - University of Michigan Press, USA, 1972. - 308 p.

Cabañas J. S. Errant in Time and Space: A Reading of Leonora Carrington's Major Literary Works. PhD Thesis / Julia Salmeron Cabañas. - University of Hull, 1997. - 258 p.

Drout M. A Way with Words IV: Understanding Poetry / Michael D. C. Drout. - Norton, Massachusetts, 2008. - 121 p.

Gascoyne D. Poems [Электронный ресурс] / David Gascoyne // PoemHunter.Com - The World's Poetry Archive. - 2012. -

Режим доступа: www.poemhunter.com/poem/and-the-seventh-dream-is-the-dream-of-isis/

Gascoyne D. Collected Poems / D. Gascoyne. - London, 1965. - 164 p.

Jackaman R. View from the White Cliffs: A Close Look at One Manifestation of English Surrealism. / Rob Jackaman // Twentieth

Century Literature. - 1975. - T. 21, № 1. - P. 72-80.

Jałocha A. The sleep of reason produces surreality. Surrealism in the context of dreams / Aneta Jałocha // Magazyn antropologicznospołeczno-kulturowy "Maska”, Iss. 30, 2016. - P. 75-85.

Matthews J. H. Surrealism and England / J. H. Matthews // Comparative Literature Studies. - 1964. - Vol. 1, no. 1. - Pp. 55-72. Quinn Sh. Surrealist imagery and the right brain. PhD Thesis. / Shelley Quinn. - The University of Alberta. Edmonton, Alberta, 1985. -300 p.

Remy M. Surrealism in Britain. / M. Remy. - Aldershot, Hants, England; Brookfield, Vt.: Ashgate, 1999. - 404 p.

Scott R. L. David Gascoyne. From Darkness into Light: A Study of Poetry 1932-1950. PhD Thesis / R. L. Scott. - University

of Northumbria, Newcastle, 2002. - 346 p.

Stockwell P. The Language of Surrealism / P. Stockwell. - London, Macmillan Int. Higher Education, 2017. - 248 p.

\section{REFERENCES}

Andreev, L. G. (2004). Sjurrealizm = Surrealisme : Istorija. Teorija. Praktika [Сюрреализм = Surrealisme : История. Теория. Практика]. Moskva : Geleos.

Aspley, K. (2010). Historical dictionary of surrealism. Lanham Md.: Scarecrow Press.

Barthes, R. (1989). Semiotika. Pojetika (Izbrannye raboty) [Избранные работы] Moskva, Progress.

Breton, A. (1969). Manifestoes of surrealism. University of Michigan Press.

Cabañas, J. S. (1997). "Errant in Time and Space": A Reading of Leonora Carrington's Major Literary Works, PhD Thesis,

University of Hull.

Drout, M. D. C. (2008). A way with words IV: Understanding poetry. Prince Frederick, MD: Recorded Books.

Frejd, Z. (2010). Tolkovanie snovidenij. [Толкование сновидений]. Sankt-Peterburg: Azbuka-klassika.

Gascoyne, D. Poems. Retrieved January 22, 2019, from

www.poemhunter.com/poem/and-the-seventh-dream-is-the-dream-of-isis/

Gascoyne, D. (1965) Collected Poems. London.

Jackaman, R. (1975). View from the White Cliffs: A Close Look at One Manifestation of English Surrealism. Twentieth Century Literature, 21(1), pp. 72-80.

Jałocha, A. (2016). The sleep of reason produces surreality. Surrealism in the context of dreams. Magazyn antropologicznospołeczno-kulturowy "Maska", 30, pp.75-85.

Jakobson, R. (1975) Lingvistika i pojetika. Strukturalizm: «za» i «protiv». [Лингвистика и поэтика. Структурализм: «за» и «против»]. М.: Progress, pp. 193-230.

Lotman, Ju. М. (1992). Kul'tura i vzryv [Культура и взрыв. Семиотика]. M.: Progress Gnozis.

Matthews, J. H. (1964) Surrealism and England. Comparative Literature Studies. Vol. 1, no. 1. Pp. 55-72.

Mazin, V. A. (2004). Vvedenie v Lakana [Введение в Лакана]. M.: Pragmatika kul'tury.

Quinn, S. (1985). Surrealist imagery and the right brain, PhD Thesis, The University of Alberta, Edmonton.

Remy, M. (1999). Surrealism in Britain. Aldershot, Hants, England; Brookfield, Vt.: Ashgate.

Scott, R. L. (2002). David Gascoyne. From Darkness into Light: A Study of poetry 1932-1950, PhD Thesis, University of

Northumbria, Newcastle.

Shvec, N. N. (2008). Slovar' egipetskoj mifologii. [Словарь Египетской Мифологии. Загадки Древнего Египта]. Моskva:

Centrpoligraf.

Stepanov, Ju. S. (2006). Semiotika i Avangard: Antologija [Семиотика и авангард: антология]. Moskva: Kul'tura Akad. Proekt.

Ster'jopulu, A. Je. (2008). Vvedenie v sjurrealizm. [Введение в сюрреализм]. L'vov: BaK

Stockwell, P. (2017) The Language of Surrealism. London, Macmillan Education. 


\begin{abstract}
Анотація
Сюрреалізм, літературний та мистецький рух початку XX століття, став об'єктом значної кількості наукових досліджень. Ця стаття вивчає сюрреалізм як тип художнього мислення, який підняв роль несвідомого в поезії, та зосереджується на центральному понятті сюрреалістичної естетики - автоматичному образі, який дозволив поетам вивчати ірраціональні стани.

Орієнтуючись на дослідження сновидіння, сюрреалісти створили поезію, що наповнена специфічними образами, які, надходячи безпосередньо з несвідомого, несуть нові знання про світ та людей. Поет - лише провідник, тому саме читач повинен відшукати сенс цієї поезії.

У статті розглядається сюрреалізм з точки зору лінгво-поетичного експерименту та аналізуються лінгвістичні характеристики автоматичних текстів у ранній поетичній збірці Девіда Гаскойна (1916-2001). Висвітлено особливості прийомів творчості британського поета, які побудовані на французьких сюрреалістичних концепціях і теоріях, а також розглянуто фонетичні, семантичні та синтаксичні аспекти його поезії.

Тексти Девіда Гаскойна демонструють прихильність поета до французької версії сюрреалізму, його зацікавленість у несвідомому і сновидіннях. Потоки довільних візуальних образів, глибока емоційність, художне використання слова, смислові прирости сенсу роблять тексти Гаскойна відкритими для інтерпретації. Поет надає перевагу створенню насамперед візуальних образів, використовуючи спеціальну лексику (ми бачимо сновидіння), але неповторна канва його лірики створюється не тільки лексичними, але й фонетичними повторами, через інтонацію, в якій лексеми набувають нове смислове навантаження.
\end{abstract}

\title{
Ключові слова
}

Сюрреалізм, Андре Бретон, сновидіння, автоматичне письмо, сюрреалістичний образ. 